\title{
既存壁式プレキャスト鉄筋コンクリート構造集合住宅建物の 桁行方向の耐震性能評価 \\ SEISMIC PERFORMANCE EVALUATION OF EXISTING WALL-TYPE PRECAST REINFORCED CONCRETE RESIDENTIAL BUILDINGS IN LONGITUDINAL DIRECTION
}

\author{
中橋芳貴*, 高木 次 郎** \\ Yoshiki NAKAHASHI and Jiro TAKAGI
}

\begin{abstract}
A significant number of wall-type precast reinforced concrete (WPC) residential buildings exist in Japan that were constructed more than 30 years ago but maintain good structural quality and seismic strength. In order to utilize this building stock, structural renovation is needed such as opening shear walls and addition of elevators, and seismic performance of pre and post renovation is to be evaluated. In authors' previous research, static pushover analysis models were created for standard existing WPC residential buildings under seismic load in the transverse direction. In this research, the models were extended for load in the longitudinal direction. The maximum base shear coefficient, which is defined as the ratio of lateral force to the building weight, is 0.73 , and the preliminary failure mechanism is beam yielding, in addition to a limited number of beam shear failures, shear cracking of walls, and bearing failure of the vertical joints. The maximum strength and the failure mechanism calculated using an existing simple seismic performance evaluation method reasonably agreed with that obtained by the models.
\end{abstract}

\section{Keywords: wall-type precast reinforced concrete structure, existing residential building, longitudinal direction, seismic performance evaluation, static pushover analysis, ultimate lateral strength \\ 壁式プレキャスト鉄筋コンクリート構造，既存集合住宅建物，桁行方向，耐震診断，静的増分解析，保有水平耐力}

\section{1.はじめに}

1960 年代半ばから大量に建設され，良質な構造躯体と高い耐震性 能を維持する壁式プレキャスト鉄筋コンクリート (WPC) 構造集合住 宅建物の活用を目的として，著者らは現存する標準設計された建物 の耐震性能を評価してきた。具体的には, 張間方向の静的増分解析 モデルを作成し, 崩壊形と保有水平耐力を評価すると共に, プレキャ スト鉄筋コンクリート $(\mathrm{PCa})$ 耐震壁板に開口を新設した場合につい て評価した ${ }^{1-5)}$ 。解析モデルでは, 耐震壁を弾性線材に置換し, 各 接合部を弾塑性ば㸚とした。水平接合部の引張方向の復元力特性に ついては, 実大スケールでの要素実験を行い詳細な評価を行った ${ }^{2)}$ その結果，張間方向の基礎固定の解析モデルにおいて，保有水平耐 力時の 1 階の層せん断力係数は 0.64 であり, 鋁直接合部のせん断破 壊を伴う連層壁のロッキングが崩壊形となることを確認した。また, 鉛直接合部の復元力特性について, 既往研究を分析すると共に, ば らつきの大きいせん断強度および変形性状について, それらのモデ ル設定が建物挙動に与える影響を評価した ${ }^{3)}$ 。その結果, 鉛直接合
部のモデル化のうち, 最大耐力後の負勾配值および残留耐力值と最 大耐力を与えるずれ变位の設定が建物の保有耐力および崩壊挙動に 与える影響は限定的であることを確認した。

本研究では，これまで扱ってきた標準設計建物について，桁行方 向の静的増分解析モデルを作成し, 耐震性能評価を行う。また,「既 存壁式プレキャスト鉄筋コンクリート造建築物の耐震診断指針」 ${ }^{6)}$ （以下「診断指針」と呼ぶ）に準拠した耐震診断結果と比較を行う。 建物の解析的な挙動評価は接合部の復元力特性に大きく依存するが, 本研究ではそれらの全てについて必ずしも厳密な評価はできていな い。利用可能な情報をもとに, 工学的に概初妥当と考えられる WPC 集合住宅建物の解析モデルの一例を示し，その挙動評価を通じて， 同建物の耐震性能評価のための一資料を提示する。

\section{2. 解析モデル}

\section{1 建物の架構とモデル化の概要}

著者らがこれまで検討してきた標準設計された 5 階建 WPC 構造集
* (株ジェイアール東日本建築設計事務所 修士(工学)

** 首都大学東京都市環境科学研究科 准教授. Ph. D .
JR East Design Corporation, M. Eng.

Assoc. Prof., Div. of Architecture and Urban Studies, Tokyo Metropolitan Univ., Ph. D. 
合住宅建物 ${ }^{1)}$ の基準階平面図を図 1 に示す。 5 通りと 9 通りを境と して各階で階段を共有する 2 住戸の基本単位が反復されることから， 1 通りから 5 通りまでを解析の対象とし, 2 次元の静的増分解析モデ ルを作成した。この場合, 5 通り付近の桁行方向の耐震壁は半分の 長さで評価されることになり, 建物全体を扱った場合よりも耐力を 低く評価することになる。実際, 後述の耐震診断では, 建物全体と 5 通りまでの 1 階段室単位の累積強度指標を比較した場合, 建物全 体の場合の方が 1 階段室単位の場合よりも7\%程高い值になった。本

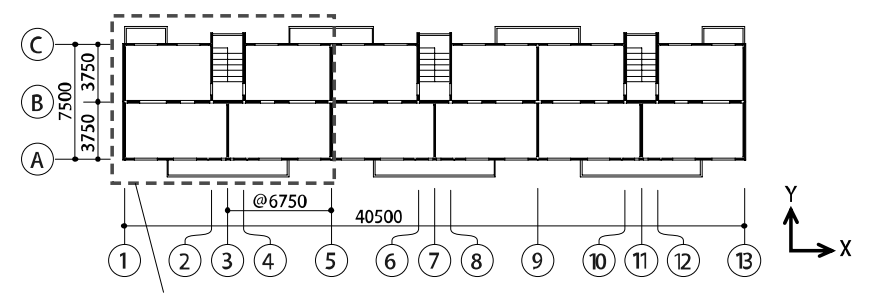

解析対象範囲(1階段室分の基本単位) $\quad-X$ 方向 $\longleftarrow \longrightarrow+X$ 方向

図 1 検討対象建物の基準階平面図

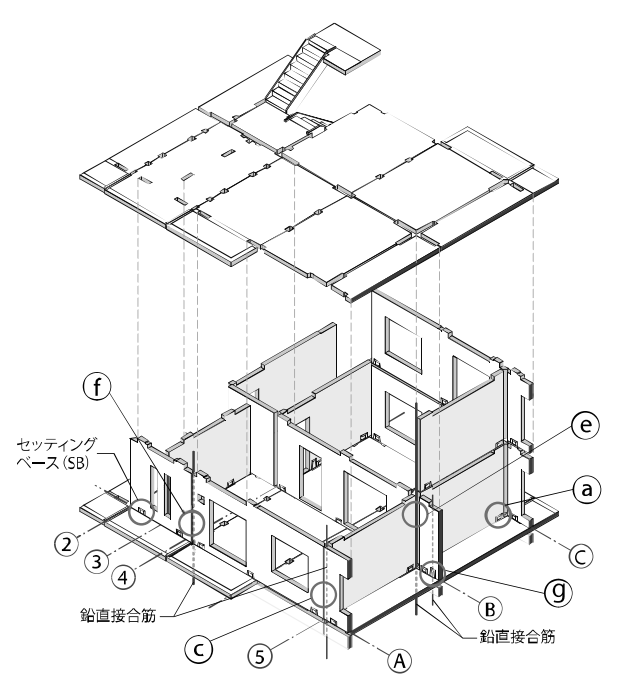

(C) (5) 1 (A)

図 2 WPC 構造集合住宅の構成

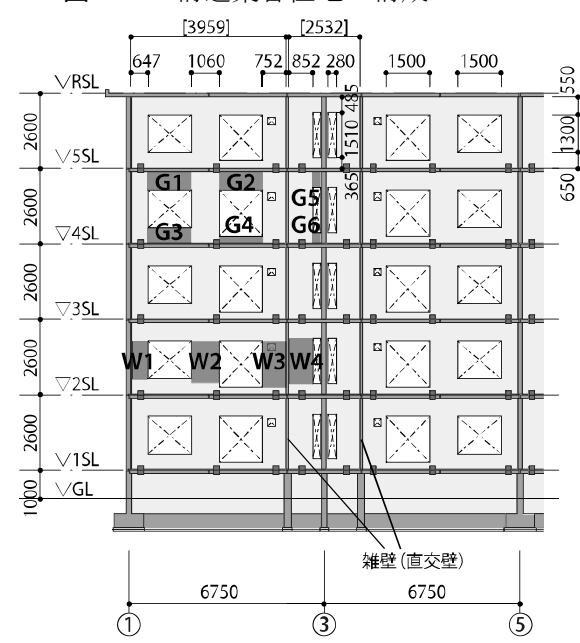

(a) $\mathrm{A}$ 構面
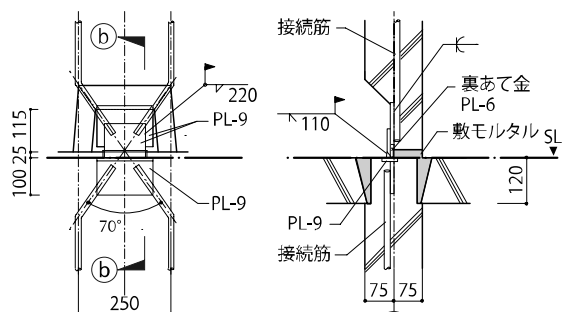

(A) b-b 断面

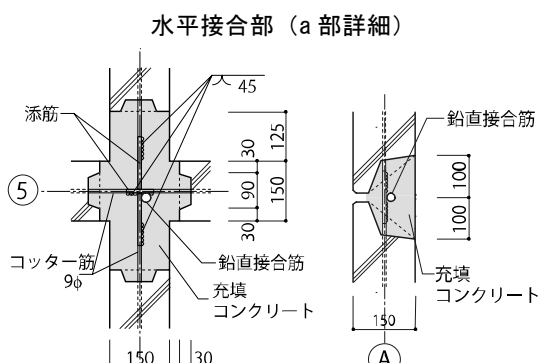

$\frac{150 \|}{1 .} \mid \|_{30} 30$

(B)

e 部詳細

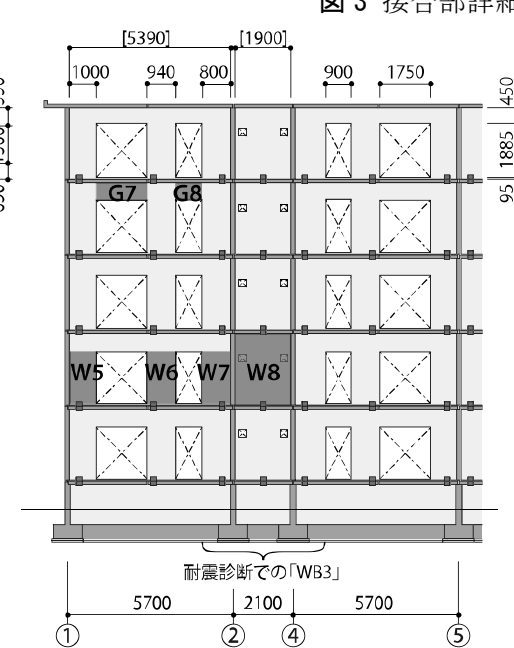

(b) $B$ 構面

図 4 検討対象建物の桁行方向軸組図

\section{f 部詳細}

解析では, 図 1 の建物を対象とするが, 階段室の数に依存しない汎 用性の高い評価を目的として，1 階段室単位をモデル化することと した。この場合, モデルは 3 通りに関して対称になることから, 解 析は図 1 の+X方向のみ行った。

一住戸分の $\mathrm{PCa}$ 板の構成を図 2 に，水平接合部および鉛直接合部 の詳細を図 3 に示寸。水平接合部は, 上下階の PCa 耐震壁板の接合 部であり，鉛直接合部は，平面的に隣接する壁板の接合部である。 基礎梁と壁板との接合は，図 3 の水平接合部が用いられている。ま た，鉛直接合部の後打ちコンクリート内の鉛直方向の鉄筋（図 2,3 の c, e, f 部) および B 通り構面 PCa 壁板に埋設され上下の連続する 壁板に接合される鉄筋（図 2,3 の $\mathrm{g}$ 部）を鉛直接合筋と呼ぶが，こ の鉄筋の基礎梁への定着および継手部でのフレア溶接は鉄筋の引張 耐力を確保するのに十分な長さとなっている。

図 4 に桁行方向の軸組図を示す。A 通りと B 通り構面は各階 3 枚 の PCa 壁板で構成され, C 通り構面は階段室の開口があり, 2 枚で構 成されている。壁板の形状は各階共通であるが，下階ほど鉄筋径が

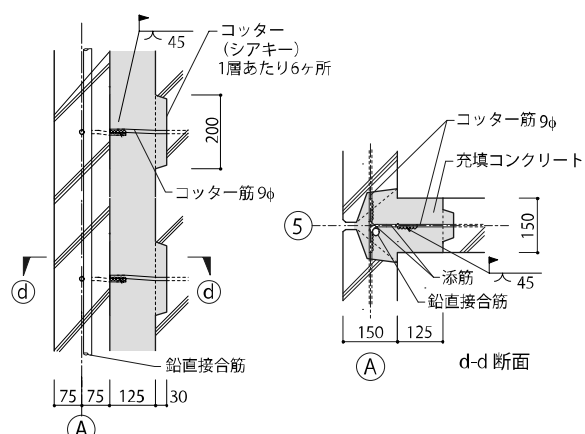

(A)

鉛直接合部（c 部詳細）

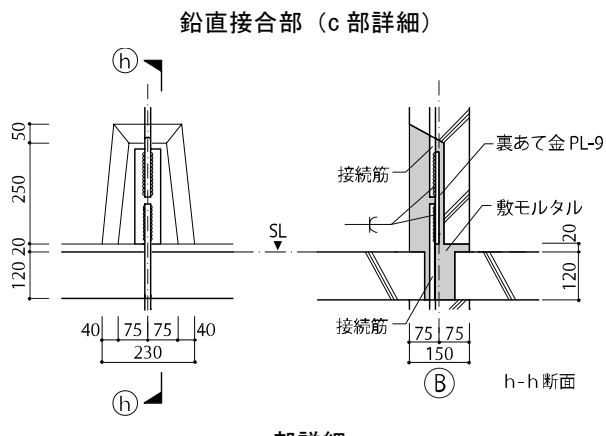

$\mathrm{g}$ 部詳細

図（図 2 の各部詳細）

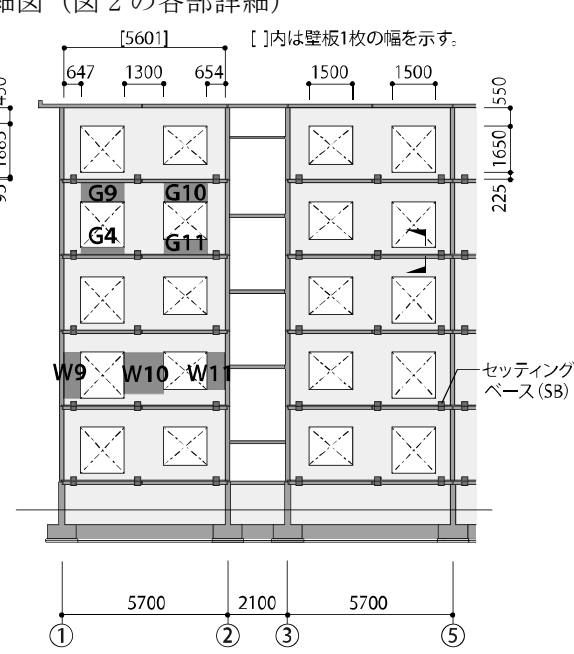

(c) C 構面 


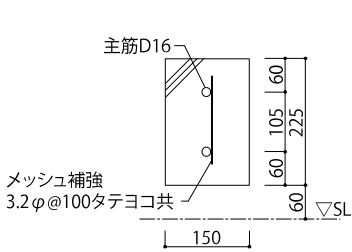

図 5 G4 壁梁断面
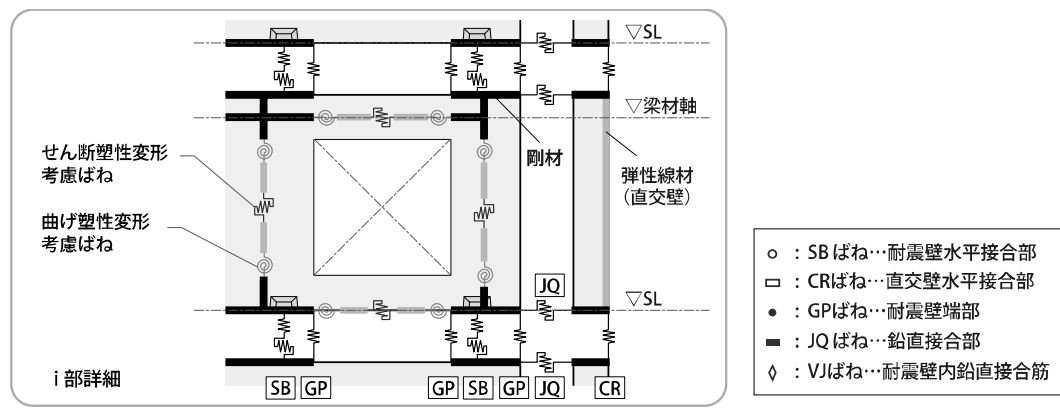

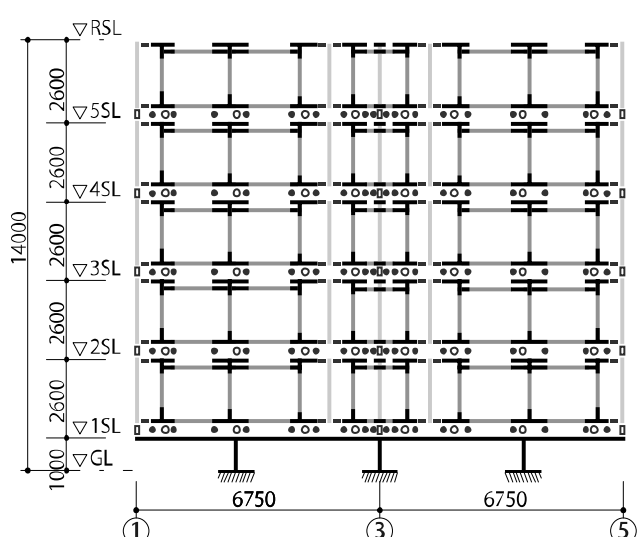

(a) $\mathrm{A}$ 構面

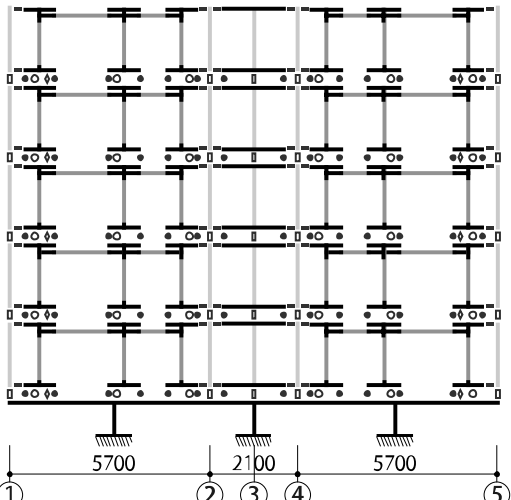

(b) $\mathrm{B}$ 構面

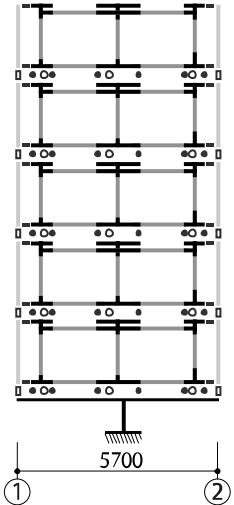

(c) $\mathrm{C}$ 構面

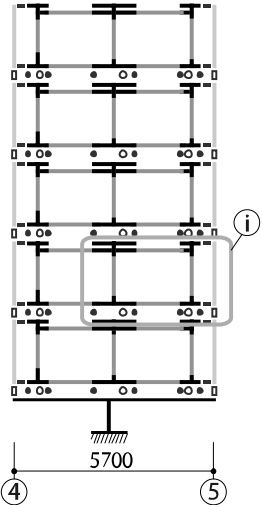

(5)

図 6 解析モデルの構成

大きく配筋されている。また，水平および鉛直接合部での接続筋や 鉛直接合筋（図 3）の径も下階ほど大きい。壁厚はいずれも $150 \mathrm{~mm}$ である。整理のため, 開口脇の壁および梁について, 図中 2 階と 4 階部分に符号を表記した。これらは各階共通である。

図 6 に解析モデルの概要を示す。長方形断面の壁および梁につい て, 塑性変形ばねを有する弾性線材とし, 曲げおよびせん断剛性は コンクリートの弾性係数を用いて算出した。壁の上下端の水平部材 および壁と梁の仕口の剛域に相当する部分を剛材とした。塑性変形 ばねおよび接合部ばねの詳細については後述する。検討方向に直交 する張間方向の壁（以下「直交壁」）については，各構面間の $1 / 2$ の壁幅と壁厚の長方形断面としてモデル化した。ここで， 1 通りの 妻壁厚は $180 \mathrm{~mm}$ で, 5 通りの壁厚 $150 \mathrm{~mm}$ よりも大きいが, これらの 直交壁厚が建物挙動に与える影響は軽微であり，いずれも $150 \mathrm{~mm}$ と して 3 通りに対する対称性を保持する形でモデル化した。また， B 通り構面の 2 通りと 4 通りの直交壁については, 住戸出入口までを 壁幅とした。そして, 基礎梁は剛体として変形を無視した。これは, 1 階床レベルは地盤レベルから $1 \mathrm{~m}$ ほど立ち上がっており, 基礎梁の 成が大きく耐力が高いことと, 地盤の状態によって杭や直接基礎の 形式が異なり, 基礎梁の支持条件が変化するためである。ただし, 特定の杭基礎を想定し, 基礎梁をモデル化した場合でも結果への影 響は軽微であることを別途確認した。剛床を仮定し，3 構面の耐震 壁上端の各階床レベルの水平变位を同一とした。

材料強度は診断指針 ${ }^{6)}$ に基づいて設定した。PCa コンクリートお よび鉛直接合部の充填コンクリートの材料強度は設計基準強度と等 しく $27 \mathrm{~N} / \mathrm{mm}^{2}$ とし, ヤング係数は $25.7 \mathrm{kN} / \mathrm{mm}^{2}$ と算出 ${ }^{8)}$ した。また, 異形鉄筋の材料強度は $344 \mathrm{~N} / \mathrm{mm}^{2}$ ，ヤング係数は $205 \mathrm{kN} / \mathrm{mm}^{2}$ とした。

図 7 に接合筋の位置と床板の割付および壁軸力算出用の支配床範 囲を示す。また，各階の接続筋を表 1 に示す。図および表中の「SB」

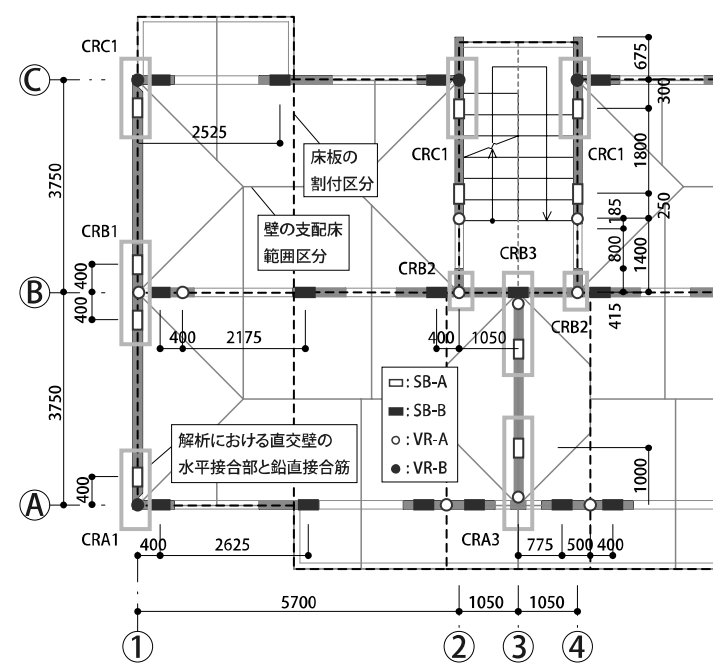

図 7 住戸内の接続筋位置

表 $1 \mathrm{SB}$ の接続筋と鉛直接合筋の配筋タイプと鉄筋径

\begin{tabular}{|c|c|c|c|c|}
\hline \multirow{2}{*}{ 階層 } & \multicolumn{2}{|c|}{ SB の接続筋 } & \multicolumn{2}{|c|}{ 鉛直接合筋 } \\
\hline & SB-A タイプ & SB-B タイプ & VR-A タイプ & VR-B タイブ \\
\hline 5 & \multirow{3}{*}{ D16 } & \multirow{4}{*}{ D16 } & \multirow{3}{*}{ D16 } & \multirow{2}{*}{ D16 } \\
\hline 4 & & & & \\
\hline 3 & & & & D19 \\
\hline 2 & D19 & & \multirow{2}{*}{ D19 } & \multirow{2}{*}{ D22 } \\
\hline 1 & D22 & D19 & & \\
\hline
\end{tabular}

および「VR」はそれぞれ，水平接合部の接続筋と鉛直接合筋を示す。 耐震壁および直交壁ごとの軸力を算出し，各階の付加鉛直荷重を壁 部材上端の節点に集中荷重として与えた。直交壁の軸力は, 隣接す る架構で 2 分割して与えた。なお, 単位面積あたりの重量（固定荷 重+積載荷重）の計算値は一般階で $8.2 \mathrm{kN} / \mathrm{m}^{2}$, R 階で $5.6 \mathrm{kN} / \mathrm{m}^{2}$ で ある ${ }^{1)}$ 。 


\section{2 接合部ばねモデル概要}

各接合部の弾塑性ばねの概要を表 2 に示寸。ばねは, 解析上 2 節 点間の全体座標系における水平, 鉛直および回転の相対変位に対す る反力の形で定義され, 表中に記載のない方向については剛性を与 えていない。

水平接合部ばね（SB ばね）では，上下階壁の水平方向のずれと鉛 直引張方向の接合筋の降伏と破断を評価した。VJ ばねは, 鉛直接合 筋による鉛直引張方向のばねであり, 鉄筋断面積に引張強度を乗じ た引張耐力を有する完全弾塑性ば拜とした。降伏時変位の設定に明 確な根拠はないが, SB ばねの鉛直方向降伏時変位 $(3 \mathrm{~mm})$ と同じと した。GP ばねは耐震壁の端部にあり, 鉛直圧縮方向のみの高剛性ば ねとした。従って, PCa 壁板の圧壊による変形は無視している。さ らに, 鉛直接合部ばね（JQ ばね）は，平面的に隣接する壁の相対鉛 直変位に対するばねであり, 鉛直接合部のせん断ひび割れおよび接 合部コンクリートから接合筋によるせん断力伝達機構への移行を評 価した。これらのばねの復元力特性の設定は, 基本的に著者らの既 往研究 ${ }^{1-5)}$ に準じるが, 建物の挙動に与える影響が特に大きいと考 えられる SB，CR および JQ ばねについて次節以降で述べる。

\section{表 2 接合部ばねの設定概要}

\begin{tabular}{|c|c|c|}
\hline 名称 & 方向 & 設定 \\
\hline \multirow[t]{2}{*}{ SB } & 水平 & 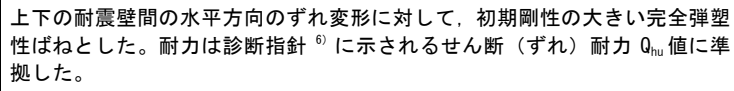 \\
\hline & 鉛直 & 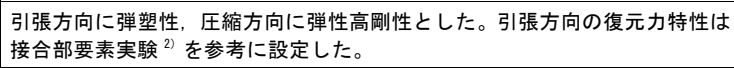 \\
\hline VJ & 鉛直 & 引張方向に, 鉛直接合筋（VR）の寄与分を完全弾塑性ばねとした。 \\
\hline CR & 鉛直 & $\begin{array}{l}\text { 引張方向に弾塑性, 圧縮方向に弾性高剛性とした。引張方向の復元力特性は } \\
\text { 真壁中の SB および VJ ばねの特性の累加とした。 }\end{array}$ \\
\hline GP & 鉛直 & 圧縮方向にのみ弾性高剛性とした。 \\
\hline \multirow[t]{3}{*}{ JQ } & 水平 & 弾性高剛性とした。 \\
\hline & 鉛直 & $\begin{array}{l}\text { 原点対称の負剛性を有するテトラリニア型の復元カ特性とした。最大耐カは } \\
\text { 「壁式プレキャスト鉄筋コンクリート造設計基準・同解説」9)に準じて算出 } \\
\text { した。 }\end{array}$ \\
\hline & 回転 & 弾性高剛性とした。 \\
\hline
\end{tabular}

\section{3 水平接合部ばねモデル}

水平接合部ばね（SB ばね）では，上下階の耐震壁の水平方向のず れと鈆直方向の引張に対する弾塑性挙動を評価する。水平方向のず れに対しては, 著者らの既往研究 ${ }^{1)}$ に準じて, 初期剛性の十分大き い完全弾塑性ばねとし，降伏時変位は $0.01 \mathrm{~mm}$ 以下とした。これは， 水平接合部のずれが発生するまで同接合部でのずれ変位はごく微小 であると考えたためである。また, せん断（ずれ）耐力は, 診断指 針 ${ }^{6)}$ における $Q_{\text {hu }}$ 值であり，その算出には壁の長期軸力を用いた。

SB ばねの鉛直引張方向の復元力特性を図 8 に示す。これらは, 著 者らによるD16 と D 19 の 2 体の実大水平接合部引張実験結果を参考 に，既往研究 ${ }^{2)}$ で同鉄筋径および D22 の場合について設定したもの である。復元力特性は 4 線で構成され, 第 1 折点は接続筋の降伏が 初めて確認された点であり, 第 2 折点は最大耐力となる接続筋の破 断点である。最大耐力時変位および鉄筋の降伏長さは 2 体の実験 ${ }^{2)}$ で鉄筋径に応じて大きくなっており, それに準じて接続筋が D22 の 場合の最大耐力時変位を設定した。

CR ばねは, 鉛直引張方向のみに機能寸るばねであり, その復元力 特性は, 直交壁中の SB ばねと VJ ばねの累加である。 SB と VJ ばね
の耐力は, 図 7 と表 1 の鉄筋径に応じて算出した。図 8 に 1 階の主 な CR ばねの復元力特性を示す。CR ばねの符号と位置は図 7 の通り である。

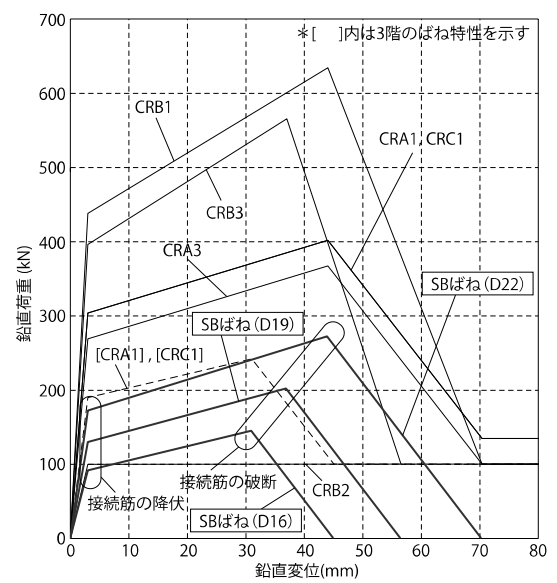

図 8 主な 1 階の $\mathrm{SB}$ および $\mathrm{CR}$ ばねの鉛直方向の復元力特性

\section{4 鉛直接合部ばねモデル}

鉛直接合部の鉛直方向の相対変位に対するばね（JQ ばね）の復元 力特性は, 図 9 のような原点対称のテトラリニア型とした ${ }^{3)}$ 。第 1 折点である接合部への斜めせん断ひび割れ発生時の耐力は最大耐力 の $1 / 3$ とし, そのときの変位を $0.05 \mathrm{~mm}$ とした。第 2 折点である最大 せん断耐力 $\mathrm{Q}_{\mathrm{su}}$ は「壁式プレキャスト鉄筋コンクリート造設計基準・ 同解説」9) に準拠した。最大耐力を与える変位 $\delta_{\mathrm{su}}$ は既往実験を参 考に $1.5 \mathrm{~mm}$ とした。最大耐力後の残留耐力はコッター筋（差筋）の せん断耐力で最大耐力の $27.7 \%$ とた。これらの復元力特性の設定 は, 既往の実験データとの比較により設定したものである ${ }^{3)}$ 。参照 した既往実験は必ずしも検討対象建物の鉛直接合部と同じ仕様では なく, 比較実験データも限定的であったことから, 妥当性は十分に は検証できていない。1 層あたり 2 箇所の JQ ばねを設定し, それぞ れに, 1 層あたりの耐力の半分を与えた。表 3 に 1 箇所あたりの JQ ばねの各折点での荷重および変位を示す。

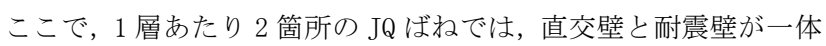
となった T形の平断面としては評価できていない。ただし，本解析 では, 接合部の弾塑性挙動が建物全体の挙動に与える影響が大きく, 直交壁つき壁柱の曲げ剛性を 10 倍に増大させた解析を行ったが, 結 果への影響はごく軽微であった。

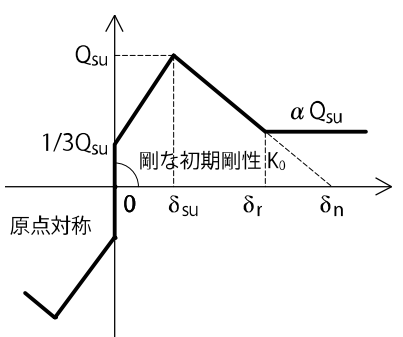

図 $9 \mathrm{JQ}$ ばねおよび壁と壁梁のせん断ばねの復元力特性

表 $3 \mathrm{JQ}$ および壁と壁梁のせん断ばねの復元力特性值

\begin{tabular}{|c|c|c|c|c|c|c|}
\hline & \multicolumn{2}{|c|}{ 第 1 折点 } & \multicolumn{2}{c|}{ 第 2 折点 } & \multicolumn{2}{c|}{ 第 3 折点 } \\
\hline & 荷重 $(\mathrm{kN})$ & 変位 $(\mathrm{mm})$ & 荷重 $(\mathrm{kN})$ & 変位 $\delta_{\mathrm{su}}(\mathrm{mm})$ & 荷重 $(\mathrm{kN})$ & 変位 $\delta_{\mathrm{r}}(\mathrm{mm})$ \\
\hline $\mathrm{JQ}$ ばね & $1 / 3 Q_{\mathrm{su}}$ & 0.05 & $Q_{\mathrm{su}}$ & 1.5 & $0.277 Q_{\mathrm{su}}$ & 8.0 \\
\hline 壁・梁 & $1 / 3 \mathrm{Q}_{\mathrm{su}}$ & $Q_{\mathrm{su}} / 3 \mathrm{~K}_{0}$ & $Q_{\mathrm{su}}$ & $0.4 \ell^{* 1)}$ & $0.4 Q_{\mathrm{su}}$ & $* 2)$ \\
\hline
\end{tabular}

$* 1): \ell(\mathrm{mm})$ は部材長さ。 $* 2):$ 最大耐力後, 部材変形角 $\delta_{\mathrm{n}}=3.6 \%$ で耐力消失するような負剛性 とし, 残留耐力 $0.4 Q_{\mathrm{su}}$ を与える変位 $\delta_{\mathrm{r}}$ とした。 


\section{5 壁梁モデル}

各開口上部および下部の壁梁は線材でモデル化し，「既存鉄筋コ ンクリート造建築物の耐震診断基準・同解説」7)に準じて, 曲げお よびせん断の終局耐力を求めた上で，塑性変形分を回転およびせん 断ばねとして集約して与えた。開口上部と下部の壁梁は，それぞれ 部材軸レベルと壁要素下部の水平剛材レベルに設けた。開口上部の 壁梁については, 曲げ耐力と剛性について床板との一体性を考慮し て図 10 のような $\mathrm{T}$ 型断面と断面 2 次モーメントが等価な長方形断面 としてモデル化した。スラブの協力幅は「鉄筋コンクリート構造計 算規準・同解説」 ${ }^{8)}$ を参考に, 梁の材軸方向スパンの 0.1 倍とした。 ここで, 梁と床板の梁の材軸方向のずれに対する剛性や耐力の評価 はできておらず, 曲げ性能について T 型断面としてモデル化するこ との妥当性は確認できていない。また, 壁式構造建物でのスラブの 協力幅の設定についても検討の余地がある。ただし, 床板の梁耐力 への寄与を変数とした解析を行っており,それについては後述する。 梁と床板の一体性やスラブの協力幅, さらに, 上階開口下部の壁と の一体性など，梁の耐力と剛性のモデル化には多くの課題が残され ている。本研究では, それらの課題を指摘するにとどめ, モデルの 一例により建物の挙動を分析する。B 通り構面の開口下部の壁梁は, 高さ $95 \mathrm{~mm}$ と短く, 梁として機能するには耐力が低いことからモデル 化していない。各壁梁の有効せい, 梁幅および配筋を表 4 に整理し た。表中配筋の 1 段目が引張鉄筋断面積 $\mathrm{a}_{\mathrm{t}}\left(\mathrm{mm}^{2}\right), 2$ 段目がスラブ筋 断面積 $\mathrm{a}_{\mathrm{s}}\left(\mathrm{mm}^{2}\right), 3$ 段目がせん断補強筋比 $\mathrm{p}_{\mathrm{w}}(\%)$ である。また, 各壁 梁の符号と位置は図 4 の通りである。

終局曲げモーメント $\mathrm{M}_{\mathrm{u}}$ は以下の式により算出した。

$$
M u=0.9\left(a_{t} \sigma_{y} d+a_{s s} \sigma_{s y} d_{s}\right)
$$

ここで ${ }_{\mathrm{s}} \sigma_{\mathrm{y}}\left(\mathrm{N} / \mathrm{mm}^{2}\right)$ は引張鉄筋の降伏点, $\mathrm{d}(\mathrm{mm})$ は壁梁の有効 せい, ${ }_{\mathrm{s}} \sigma_{\mathrm{sy}}\left(\mathrm{N} / \mathrm{mm}^{2}\right)$ はスラブ筋の降伏点, $\mathrm{d}_{\mathrm{s}}(\mathrm{mm})$ は圧縮縁からス

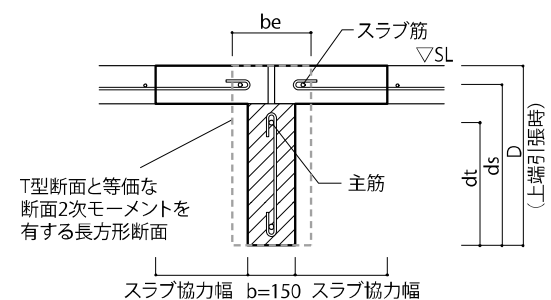

図 10 開口上部の壁梁断面
ラブ筋までの距離である。開口上部壁梁の下端引張端および開口下 部壁梁では，(1)式第 2 項を無視した。

また，終局せん断耐力 $Q_{\text {su }}$ は，床板の寄与を無視して，以下の荒 川最小式により算出した。

$$
Q_{s u}=\left\{\frac{0.053 p_{t}^{0.23}\left(F_{c}+18\right)}{M /(Q d)+0.12}+0.85 \sqrt{p_{w} \sigma_{w y}}\right\} b j
$$

ここで, $\mathrm{M} / \mathrm{Qd}$ はせん断スパン比 $(1 \leqq \mathrm{M} / \mathrm{Qd} \leqq 3) ， \sigma_{\mathrm{wy}}\left(\mathrm{N} / \mathrm{mm}^{2}\right)$ はせん 断補強筋の降伏強度, b (mm) は梁幅, $j(\mathrm{~mm})$ は応力中心間距離, $\mathrm{p}_{\mathrm{t}}(\%)$ は引張鉄筋比， $\mathrm{p}_{w}$ はせん断補強筋比 $\left(\mathrm{p}_{\mathrm{w}} \leqq 0.012\right)$ である。また, $\mathrm{F}_{\mathrm{c}}\left(\mathrm{N} / \mathrm{mm}^{2}\right)$ はコンクリートの設計基準強度であり, 診断指針 ${ }^{6)}$ に準じ て $27 \mathrm{~N} / \mathrm{mm}^{2}$ とした。

せん断破壊型の壁梁は, A 通り構面中央 G5 と G6（図 4）のみで, その他は曲げ降伏型となった。なお， G6 には壁の縦筋以外にせん断 補強筋としての配筋がないことから, 同コンクリート断面のせん断 強度を終局耐力とした。

曲げ降伏型の壁梁両端には，（1）式の終局曲げモーメントを耐力 とする完全弾塑性型の回転ばねを設けた。ここで，曲げひび割れに よる曲げ剛性低下は考慮していない。これは, 2 階の壁梁について, 曲げひび割れ耐力 $M_{c}$ は終局曲げ耐力 $M_{u}$ の 40-150\%とばらつき, すべ ての壁梁の $\mathrm{M}_{\mathrm{c}}$ を $0.4 \mathrm{M}_{\mathrm{u}}$ と仮定した場合でも崩壊形に変化はなく, 保 有耐力の低下も $1 \%$ 以下であったためである。解析モデルの単純化を 優先した。

壁梁の中央にはせん断塑性変形を考慮したばねを設けた。せん断 ばねの復元力特性は著者らによる張間方向検討時の住戸入口上部の 梁（境界梁）のモデル化 ${ }^{2)}$ と同様に, 図 9 のような原点対称のテト ラリニア型とした。初期剛性は十分剛とし，第 1 折点はひび割れ時 に相当し, その耐力は終局せん断耐力 $Q_{\mathrm{su}}$ の $1 / 3$ とした。第 2 折れ 点はせん断耐力点であり， $Q_{\mathrm{su}}$ を与える部材変形角 $\delta_{\mathrm{su}}$ は $0.4 \%$ あるる。 最大耐力後は部材変形角 $\delta_{\mathrm{n}}$ が $3.6 \%$ で耐力消失するような負剛性と し, その後の残留耐力は最大耐力の $40 \%$ とした。以上の特性值を表 3 に示す。

\section{6 壁モデル}

開口脇の壁は線材としてモデル化し，壁梁同様「既存鉄筋コンク リート造建築物の耐震診断基準・同解説」7)に準じて, 曲げおよび

表 4 壁梁断面表

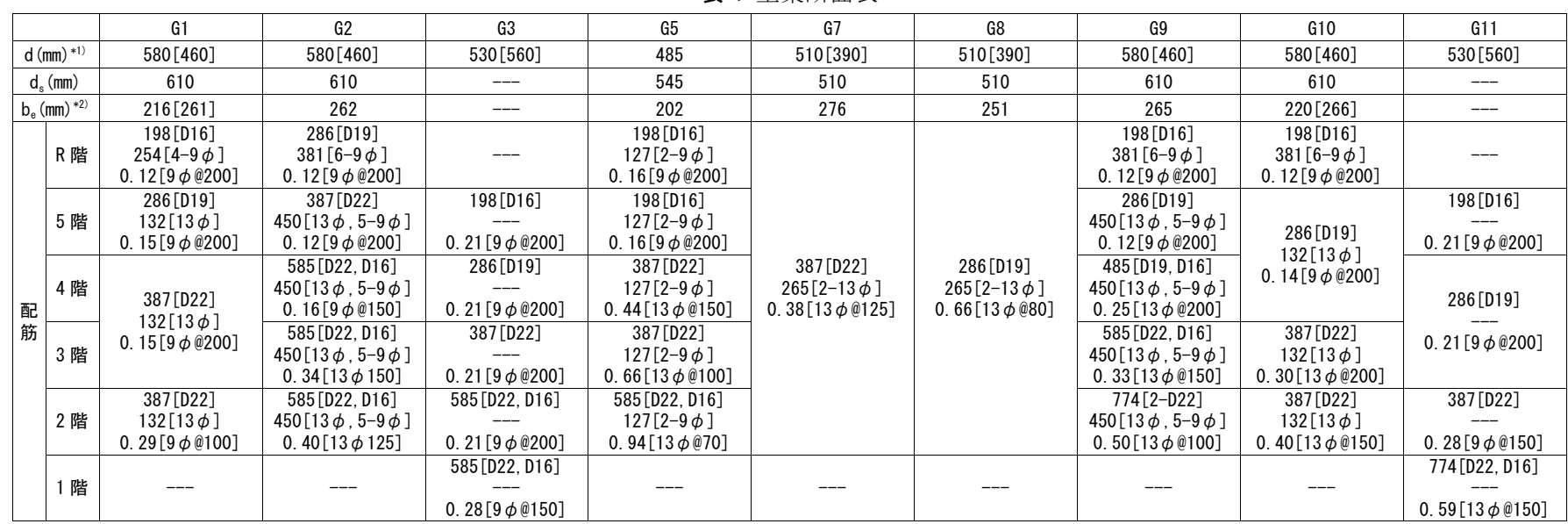

$* 1):[$ ]内は上端筋引張の場合の $d$ が下端筋引張の場合の $d$ と異なる場合の值を示す。 $* 2) ：\left[\right.$ 内内は $\mathrm{R}$ 階の $\mathrm{b}_{\mathrm{e}}$ が $2 \sim 5$ 階の $\mathrm{b}_{\mathrm{e}}$ と異なる場合を示す。 
せん断の終局耐力を算出した。

終局曲げモーメント $\mathrm{M}_{\mathrm{u}}$ は下式より算出した。

$$
M_{u}=0.8 a_{t} \sigma_{y} D+0.5 N D\left(1-\frac{N}{F_{c} b D}\right)
$$

ここで D（mm）は壁幅，b（mm）は壁厚，N（N）は長期軸力である。

一方, 終局せん断耐力 $Q_{\mathrm{su}}$ は (2) 式に圧縮軸力による強度増分 0.1 $\sigma_{0} \mathrm{bj}$ を加えた值である。 $\sigma_{0}\left(\mathrm{~N} / \mathrm{mm}^{2}\right)\left(\leqq 8 \mathrm{~N} / \mathrm{mm}^{2}\right)$ は壁の圧縮軸応 力度で長期軸力より算出した。なお, 桁行方向架構の主崩壊形は梁 の曲げあるいはせん断破壊であることを後述するが，その上で壁柱 に水平力による変動軸力を考慮した場合でも，結果への影響はごく 軽微であることを別途確認している。各壁の有効せいおよび配筋を 表 5 に示す。各壁の符号と位置は図 4 の通りである。耐震壁の配筋 は図 11 のようになっており, 引張鉄筋断面積 $\mathrm{a}_{\mathrm{t}}$ は耐震壁の縦筋を 含めず，鉛直方向の開口補強筋（柱筋）のみを考慮した。また，耐 震壁の横筋をせん断補強筋と考えた。

塑性変形ばねの復元力特性は壁梁と同様であり, 各壁に回転およ びせん断ばねを設けた。

\section{3. 解析結果}

\section{1 解析結果と考察}

解析には，汎用ソフト ${ }^{12)}$ を用いた。+X 方向載荷時の荷重-変形関 係を図 12 に点線で示す。なお, 図中の実線および一点鎖線の解析結 果については後述する。図の縦軸の荷重は Ai 分布による地震荷重に よる 1 階層せん断力係数 $\mathrm{C}_{\mathrm{Q} 1}$ を示し, 横軸の変形角 $\mathrm{R}$ は $\mathrm{R}$ 階の水平 変位を 1 階床レベル（1SL）からの高さ $13.0 \mathrm{~m}$ で除した值である。

$\mathrm{C}_{\mathrm{Q} 1}=0.38$ 程度で $\mathrm{A}$ 構面 1 通り側 2 階の壁梁（G4）と 5 通り側 3 階
の壁梁（G4）から曲げ降伏し始め， R= 0.35\%でほとんどの壁梁が曲 げ降伏した。 $\mathrm{R}=0.16 \%$ で $\mathrm{A}$ 構面 3 通り付近 2 階の壁梁 $\mathrm{G} 6$ が, $\mathrm{R}=0.22 \%$ で B 構面 4 通り付近 1 階脚部の JQ ばねが図 9 の復元力特性におうる 最大耐力に達し始め, $\mathrm{R}=0.39 \%$ 付近で $\mathrm{A}$ 構面 3 通り付近の壁梁 $\mathrm{G} 6$ の 多くが， $\mathrm{R}=0.41 \%$ 付近で $\mathrm{B}$ 構面 4 通り付近の $\mathrm{JQ}$ ばねの多くが同図の 負勾配後の残留耐力域に達した。また, 壁梁 G2, G9 においてもせん 断破壊が確認された。保有水平耐力時の $\mathrm{C}_{Q 1}$ は 0.73 であり, この時

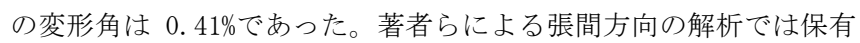
水平耐力時の $\mathrm{C}_{01}$ は 0.64 であり, この時の変形角は $0.19 \%$ であった 2)。桁行方向の最大耐力は張間方向の 1.14 倍であり, 保有水平耐力 時の変形角が大きかった。これは，張間方向では，鉛直接合部ばね

（JQ ばね）が最大耐力に達することで, 建物の保有水平耐力が決定 されたのに対し，桁行方向では，B 構面 4 通り付近の JQ ばねとせん 断破壊型壁梁がせん断破壊するものの，建物全体としては，壁梁の 曲げ降伏が支配的であったためと考えられる。壁梁を含まない解析 モデルを作成し, その荷重変位関係を図 12 に示した。これより保有 水平耐力の $75 \%$ ほどに壁梁が寄与していることが分かる。

図 13 に各階の層せん断力係数一層間変形角関係を示寸。なお, 耐 震診断結果を示寸図中の点線については後述する。上階ほど各階の 層せん断力係数 $\mathrm{C}_{Q \mathrm{i}}$ は大きく, 保有水平耐力時の層間変形角は 2 階 で $0.5 \%$ と最大であった。

図 14 に保有水平耐力時の架構毎の負担地震荷重を示す。 $\mathrm{A}$ 通り構 面の負担率がやや高く, C 通り構面の負担率がやや低い。C 通り構面 の低負担率は階段室があるためである。負担軸力が大きい $\mathrm{B}$ 通り構 面の分担率が $\mathrm{A}$ 通り構面より小さいが，これは B 通り構面では開口 下部の壁梁がないことに加え，開口上部の壁梁も比較的に耐力が小

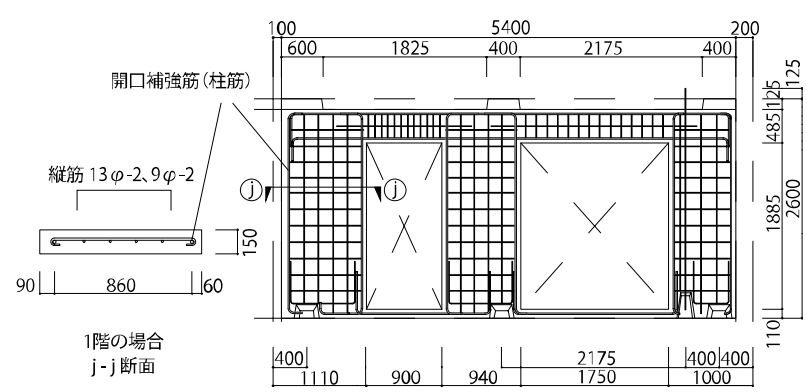

図 11 耐震壁の配筋図（B 構面 W5-7 の場合）

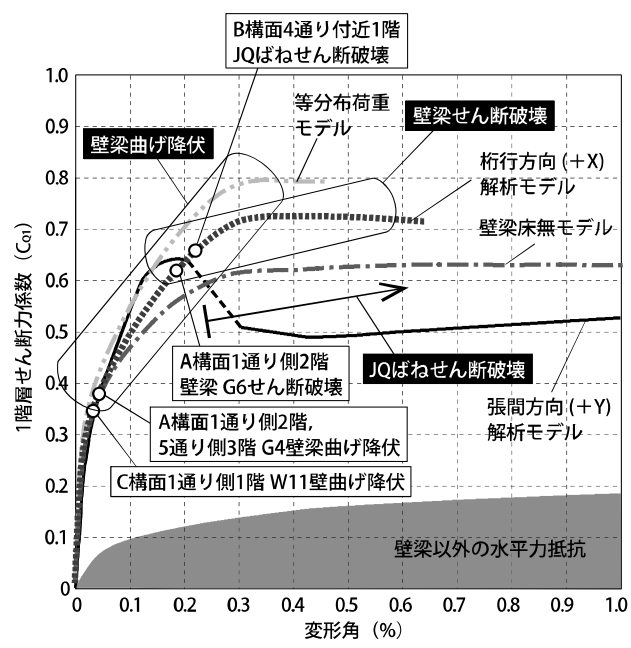

図 12 各解析モデルの荷重-変形関倸

\begin{tabular}{|c|c|c|c|c|c|c|c|c|c|c|c|c|}
\hline & & W1 & W2 & W3 & W4 & W5 & W6 & W7 & W8 & W9 & W10 & W11 \\
\hline \multicolumn{2}{|c|}{$\mathrm{d}(\mathrm{mm})^{* 1)}$} & $\begin{array}{c}407 \\
{[467]}\end{array}$ & 970 & $\begin{array}{c}662 \\
{[602]}\end{array}$ & $\begin{array}{r}702 \\
{[762} \\
\end{array}$ & 740 & 880 & 920 & 1810 & \begin{tabular}{|c|}
497 \\
{$[557]$}
\end{tabular} & 1210 & $\begin{array}{c}564 \\
{[504]}\end{array}$ \\
\hline \multirow{5}{*}{$\begin{array}{c}a_{t} \\
\left(\mathrm{~mm}^{2}\right)\end{array}$} & 5 階 & \begin{tabular}{|c|c}
198 \\
{$[D 16]$}
\end{tabular} & & & & \multirow{4}{*}{$\begin{array}{c}198 \\
{[D 16]}\end{array}$} & \multirow{3}{*}{$\begin{array}{c}198 \\
\text { [D16] }\end{array}$} & \multirow{4}{*}{$\begin{array}{c}198 \\
\text { [D16] }\end{array}$} & \multirow{5}{*}{$\begin{array}{c}198 \\
\text { [D16] }\end{array}$} & \begin{tabular}{|c|}
198 \\
{$[D 16]$}
\end{tabular} & \multirow{5}{*}{$\begin{array}{c}198 \\
\text { [D16] }\end{array}$} & \multirow{5}{*}{$\begin{array}{c}198 \\
\text { [D16] }\end{array}$} \\
\hline & 4 階 & 286 & $\begin{array}{c}198 \\
{[D 16]}\end{array}$ & $\begin{array}{c}198 \\
{[D 16]}\end{array}$ & $\begin{array}{r}198 \\
\text { [D16. }\end{array}$ & & & & & $\begin{array}{c}397 \\
{[2-D 16} \\
\end{array}$ & & \\
\hline & 3 階 & [D19] & & & & & & & & \begin{tabular}{|l}
485 \\
{$[D 19$,} \\
$D 16]$ \\
\end{tabular} & & \\
\hline & 2 階 & \multirow{2}{*}{$\begin{array}{c}387 \\
{[\mathrm{D} 22]}\end{array}$} & \multirow{2}{*}{$\begin{array}{c}286 \\
\text { [D19] }\end{array}$} & \multirow{2}{*}{$\begin{array}{c}286 \\
\text { [D19] }\end{array}$} & \multirow{2}{*}{$\begin{array}{c}286 \\
{[\mathrm{D} 19]}\end{array}$} & & $\begin{array}{c}286 \\
\text { [D19] }\end{array}$ & & & 673 & & \\
\hline & 1 階 & & & & & $\begin{array}{c}286 \\
{[019]} \\
\end{array}$ & 387 & 286 & & D19] & & \\
\hline
\end{tabular}

*1) : [ ]内は左端筋引張の場合の $\mathrm{d}$ が右端筋引張の場合の $\mathrm{d}$ と異なる場合の値を示す。 *2）： $\mathrm{p}_{w}$ は全壁柱共通で 1 2 階で $0.33 \% ， 3 \sim 4$ 階で $0.25 \% ， 5$ 階で $0.21 \%$ となる。

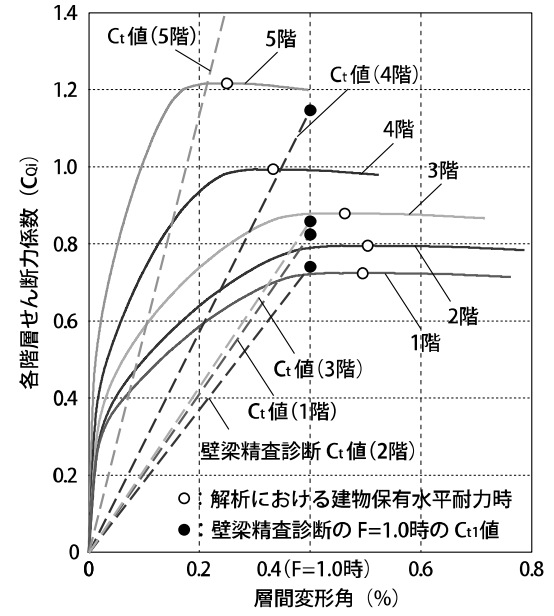

図 13 各階の層せん断力係数-層間変形角関係

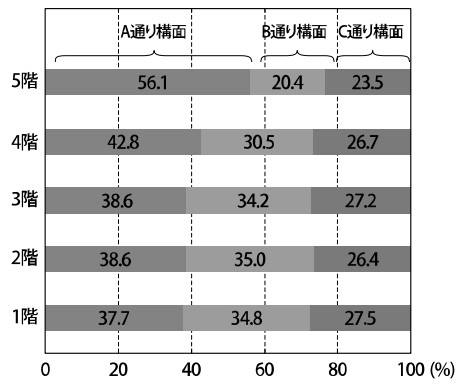

図 14 保有水平耐力時の 各構面の地震荷重分担率 
さいためと考えられる。

図 15 に桁行方向の変形と接合部ばねの損傷の様子を示す。図中 のつおよび 印は SB 鈆直方向ばね，CR ばね，JQ ばね，壁梁および 開口脇壁のせん断ばねがそれぞれ，復元力特性における第 1 折点お よび第 2 折点に到達していることを示す。壁梁および開口脇壁の回 転ばねについてはの印が降伏耐力に達していることを示す。

保有水平耐力時の JQ ばねの最大変位は $4.3 \mathrm{~mm}$ で図 9 の復元力特 性における第 3 折点に達していなかった。また, このとき SB ばねは 1 階で引張降伏したものの, 最大耐力には達しなかった。さらに, 開口脇の壁は, $\mathrm{C}_{Q 1}=0.27$ で $\mathrm{A}$ 構面 5 通り側の壁 W1 から順次せん断ひ び割れ耐力に達するものの, 保有水平耐力時の $\mathrm{R}=0.41 \%$ まで最大せ ん断耐力には至らなかった。また， $\mathrm{C}_{Q 1}=0.35$ で C 構面 1 通り側 1 階 のW11 壁から曲げ降伏し，保有水平耐力時には開口脇の壁の多くが 曲げ降伏した。

\section{2 既往実大実験との比較}

1967 年に当時の建設省建築研究所で 1 階段室型 5 階建 WPC 構造建 物の桁行方向の実大実験が行われた。既往文献 ${ }^{10,11)}$ からは, 配筋等 の詳細な情報が確認できていないことから，解析的に再現できない が，報告されている挙動の概略と本解析結果を比較する。実験建物 では本研究対象建物よりも, 全構面で PCa 壁板の幅が小さく枚数が 多い。1 枚の PCa 壁板に対し原則として開口が 1 つのみである。そ して, 本研究対象建物の $\mathrm{C}$ 通り構面に相当する構面の開口が小さく, 全構面で水平接合部の数が 1 つずつ多い。水平力の載荷モードは本 解析では Ai 分布であるのに対し，各階等分布である。

実験における最大水平耐力時の 1 階の層せん断力係数 $\mathrm{C}_{Q 1}$ は 1.5 程度であり，これは，本解析による同值 0.73 の約 2 倍である。その 原因については十分に解明できていないが，上記の配筋や載荷条件 のほか，壁梁の耐力評価の影響も考えられる。実験における構造物 の挙動は, $\mathrm{C}_{Q 1}=0.2$ 付近で壁梁に曲げひび割れが発生し, $\mathrm{C}_{Q 1}=0.6$ 付近で 1 階の水平接合部のずれ破壊が確認され, $\mathrm{C}_{Q 1}=0.9$ 以降でず れ変形が全体変形に占める割合が $30 \%$ 弱となった。さらに, $\mathrm{C}_{01}=1.5$ 付近で壁のせん断破壊が発生し耐力が低下した。本解析では，水平 接合部のずれ変形は，ほとんど確認されていない。同変形に対する ばね梡全弾塑性モデルであり，1階部分の同ばねの耐力和の 2 階 以上の建物重量に対する比は 1.9 である。すなわち，各水平接合部 のずれが等しいと仮定すると, $\mathrm{C}_{\mathrm{Q} 1}=1.9$ までずれはほとんど生じない 計算になる。既往研究からは水平接合部のずれに対する最大耐力以
外の変位についての情報が十分に得られておらず，また，著者らの 既往研究 ${ }^{4)}$ でも，その精密な復元力特性の評価の必要性が十分に認 識されていなかったこともあり，完全弾塑性モデルとしたが，その 設定に改良の余地があることを示唆している。ただし， $C_{Q 1}=0.6$ を超 える水平力下でのみ確認される同変形に対して, 挙動を精查する意 義については，検討が必要である。

実験と解析との最大耐力（保有水平耐力）の違いの原因を考える 目的で，地震荷重を各階等分布としたモデル（等分布荷重モデル） を作成した。等分布荷重モデルの荷重変形関係を図 12 に示す。 $\mathrm{C}_{Q 1}=0.37$ で $\mathrm{C}$ 構面 1 階の開口脇壁 W11 が曲げ降伏し, $\mathrm{C}_{Q 1}=0.41$ で $\mathrm{A}$ 構面 1 通り側 2 階の壁梁 $\mathrm{G} 4$ から曲げ降伏した。保有水平耐力時の $\mathrm{C}_{Q 1}$ は 0.80 であり，このときせん断破壊している壁はなかった。載 荷方法を等分布に変更することにより，保有水平耐力は $10 \%$ 上昇し たが，ずれ破壊した SB ばねは存在しなかった。

また，壁梁のモデル化が解析結果に及ぼす影響についても検討し た。前節の解析モデルでは，開口上部の壁梁について，床板との一 体性を考慮したが，梁の耐力と剛性については，床との一体性のほ か，上階開口下部の壁との一体性など, WPC 構造固有の評価の難し さがある。そこで，壁梁のモデル化の代替例として，床板の寄与を 無視した解析モデル（壁梁床無モデル）を作成した。壁梁床無モデ ルでは, 開口上部の壁梁を図 10 の斜線部分のみ考慮した。床板を考 慮した場合に比べ，上端引張時の曲げ耐力は約半分になった。壁梁 床無モデルの荷重変形関係を図 12 に示す。 $\mathrm{C}_{Q 1}=0.36$ で B 構面 1 通り 側 3 階の壁梁 G8 から曲げ降伏し始め, R= 0. 35\%でほとんどの壁梁が 曲げ降伏した。 $\mathrm{R}=0.16 \%$ 付近で $\mathrm{A}$ 構面 3 通り付近の壁梁が， $\mathrm{R}=0.23 \%$ 付近で 1 階脚部の JQ ばねがせん断破壊し始め, $\mathrm{R}=0.5 \%$ 付近で $\mathrm{A}$ 構面 3 通り付近の壁梁の多くがせん断破壊した。保有水平耐力時の $\mathrm{C}_{Q 1}$ は 0.63 であり,この時の変形角は $0.88 \%$ あった。床板を考慮しな いことにより保有水平耐力時の $\mathrm{C}_{Q 1}$ は $14 \%$ 低下した。一方，上階開口 下壁との一体性などの理由から，実際の壁梁の耐力が解析モデルの 設定值よりも高い場合を想定して，耐力を一様に 2 倍と仮定した場 合， $C_{Q 1}$ 值は $27 \%$ 上昇した。従って，壁梁の耐力評価が建物耐力に大 きく影響することが分かる。

\section{4. 耐震診断との比較}

本章では解析と耐震診断の比較検討を行う。診断は，診断指針 ${ }^{6)}$ の第 2 次耐震診断手法に準拠した。診断では，壁梁による壁の曲げ 耐力への寄与について, 梁からの曲げモーメントによる効果と壁の

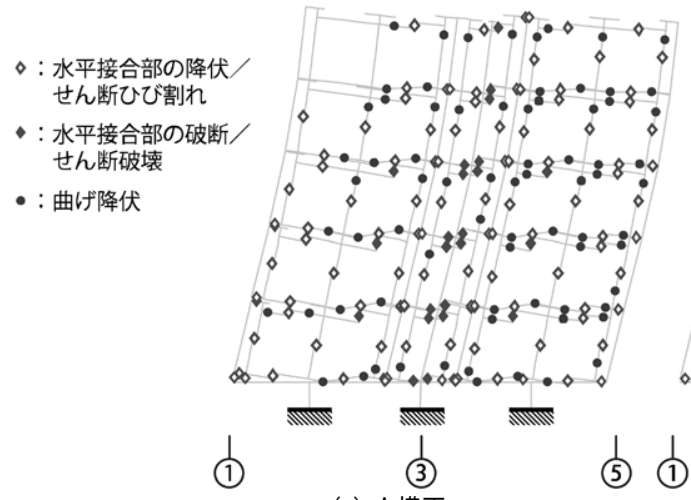

(a) $\mathrm{A}$ 構面

図 15 保有水平耐力時変形図 $(R=0.41 \%$ 時)

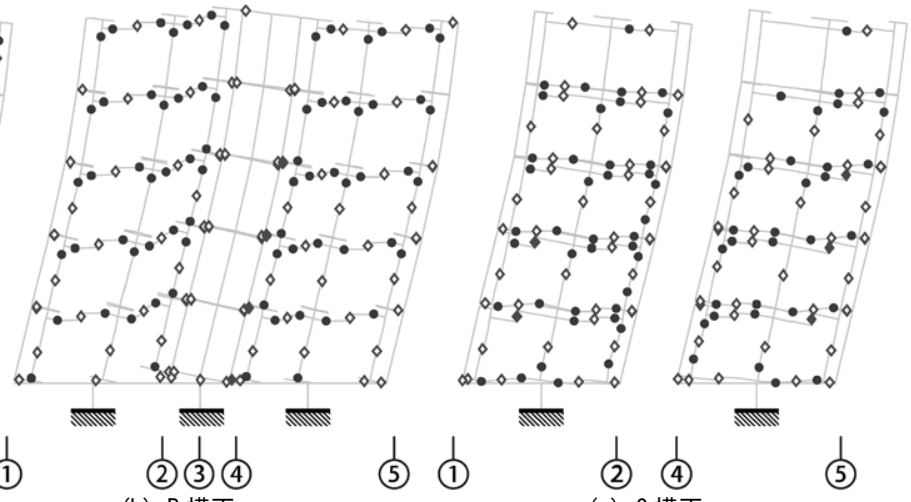

(c) C 構面 
引張側に取り合う梁のせん断力による転倒抵抗のそれぞれについて， 壁軸力に係数を乗じる形で略算することとしているが, 前節での解 析的な検討において, 曲げ戻しの効果が水平耐力に占める割合が大 きいことが確認されたことから, 同効果を精查した場合と, 診断指 針通りの略算とした場合との比較を行う。さらに, 壁梁の耐力に床 板の寄与を無視した場合についても検討した。

診断指針通りの略算による場合, 梁による壁の曲げ耐力への寄与 は, 壁に取り合う梁の数や位置に応じて算出され, 梁の耐力は考慮 されない。開口下部には一部に成が $200 \mathrm{~mm}$ 程度の梁 G4（図 5) が存 在し, これを梁として考慮する場合としない場合の両方で診断を行 った。表 6 に実施した耐震診断ケースとそれぞれのケースの診断条 件および結果を整理した。解析における保有水平耐力時の $\mathrm{C}_{Q 1}$ は変 形角 $\mathrm{R}=0.41 \%$ 時のものであり, この比較として診断では, 累積強度 指標 $\mathrm{C}_{\mathrm{t}}$ 值の $\mathrm{F}=1.0$ 時（層間変形角 $\mathrm{R}=0.4 \%$ ）のもの「 $\mathrm{C}_{\mathrm{t} 1}$ 值」を示す。 次節以降に，診断条件の基本形として壁の曲げ耐力への寄与を精査 し, 解析モデル同様, 図 1 の基本単位を対象とした場合の診断条件 および結果を述べる。続いて,その他の比較検討形について述べる。

表 6 解析值と耐震診断值の比較

\begin{tabular}{|c|c|c|c|c|c|c|c|c|c|}
\hline & \multicolumn{8}{|c|}{ 耐震診断 } & \multirow[b]{2}{*}{ 解析 } \\
\hline $\begin{array}{c}\text { 診断ケース } \\
\text { 名称 }\end{array}$ & \multicolumn{2}{|c|}{$\begin{array}{l}\text { 壁梁精査 } \\
\text { (基本形) }\end{array}$} & \multicolumn{2}{|c|}{$\begin{array}{c}\text { 壁梁床無 } \\
\text { (此較検討形) }\end{array}$} & \multicolumn{2}{|c|}{$\begin{array}{c}\text { G4 考慮 } \\
\text { (比較検討形) }\end{array}$} & \multicolumn{2}{|c|}{$\begin{array}{c}\text { 指針準拠 } \\
\text { (比較検討形) }\end{array}$} & \\
\hline 壁梁寄与 & \multicolumn{2}{|c|}{ 精査 } & \multicolumn{2}{|c|}{ 精査 } & \multicolumn{2}{|c|}{ 指針準拠 } & \multicolumn{2}{|c|}{ 指針準拠 } & (精査) \\
\hline G4 壁梁 & \multicolumn{2}{|c|}{ 考慮 } & \multicolumn{2}{|c|}{ 考慮 } & \multicolumn{2}{|c|}{ 考慮 } & \multicolumn{2}{|c|}{ 非考慮 } & 考慮 \\
\hline 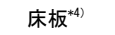 & \multicolumn{2}{|c|}{ 考慮 } & \multicolumn{2}{|c|}{ 非考慮 } & \multicolumn{2}{|c|}{ 考慮 } & \multicolumn{2}{|c|}{ 考慮 } & 考慮 \\
\hline 耐震性能 & $\mathrm{C}_{\mathrm{t} 1}$ 值*1) & $\mathrm{I}_{\mathrm{s}}$ 值 ${ }^{* 2)}$ & $C_{t 1}$ 値 & $\mathrm{I}_{\mathrm{s}}$ 値 & $\mathrm{C}_{\mathrm{t} 1}$ 值 & $\mathrm{I}_{\mathrm{s}}$ 値 & $\mathrm{C}_{\mathrm{t} 1}$ 值 & $\mathrm{I}_{\mathrm{s}}$ 值 & $\mathrm{C}_{01}$ 值 ${ }^{* 3)}$ \\
\hline 5 階 & 2. 28 & 2. $28 \mathrm{~S}$ & 2. 21 & 2. $21 \mathrm{~S}$ & 1.93 & 2. $14 \mathrm{D}$ & 1. 90 & 2. $09 \mathrm{D}$ & \multirow{5}{*}{0.73} \\
\hline 4 階 & 1. 14 & $1.14 \mathrm{~S}$ & 1.07 & 1. $31 \mathrm{D}$ & 0.95 & $0.95 \mathrm{D}$ & 0.90 & $0.96 \mathrm{D}$ & \\
\hline 3 階 & 0.86 & $1.03 \mathrm{D}$ & 0.76 & $0.88 \mathrm{D}$ & 0.79 & $0.79 \mathrm{~S}$ & 0.75 & $0.75 \mathrm{~S}$ & \\
\hline 2 階 & 0.74 & $0.89 \mathrm{D}$ & 0.65 & $0.76 \mathrm{D}$ & 0.80 & $0.80 \mathrm{~s}$ & 0.75 & $0.75 \mathrm{~S}$ & \\
\hline 1 階 & 0.82 & $0.82 \mathrm{~S}$ & 0.71 & $0.71 \mathrm{~s}$ & 0.87 & $0.87 \mathrm{~S}$ & 0.81 & $0.81 \mathrm{~s}$ & \\
\hline
\end{tabular}

$* 1): \mathrm{C}_{\mathrm{t} 1}$ 值は $\mathrm{F}=1.0$ 時の值を示す。 $\left.* 2\right)$ : 数值後の「D」は靯性型, 「S」は強度型の算定式で 決定されたことを示す。 $* 3): \mathrm{C}_{01}$ 值は保有水平耐力時の 1 階の層せん断力係数を示す。 $\left.* 4\right)$ ： 壁梁への床板の寄与を示す。

\section{1 耐震診断の概要}

耐震診断に用いた各諸元について以下に述べる。PCa 壁板のコン クリート圧縮強度および鉄筋の材料強度は, 解析モデル同様, 診断 指針に従い $27 \mathrm{~N} / \mathrm{mm}^{2}$ および $294 \mathrm{~N} / \mathrm{mm}^{2}$ (丸鋼) と $344 \mathrm{~N} / \mathrm{mm}^{2}$ (異形鉄筋) である。耐震壁の全長 $\ell(\mathrm{mm})$, 引張り側の有効曲げ補強筋の全断面 積 $\mathrm{a}_{\mathrm{t}}\left(\mathrm{mm}^{2}\right)$, 耐震壁の引張に有効な $\mathrm{a}_{\mathrm{t}}$ 以外の縦筋の全断面積 $\mathrm{a}_{\mathrm{w}}\left(\mathrm{mm}^{2}\right)$

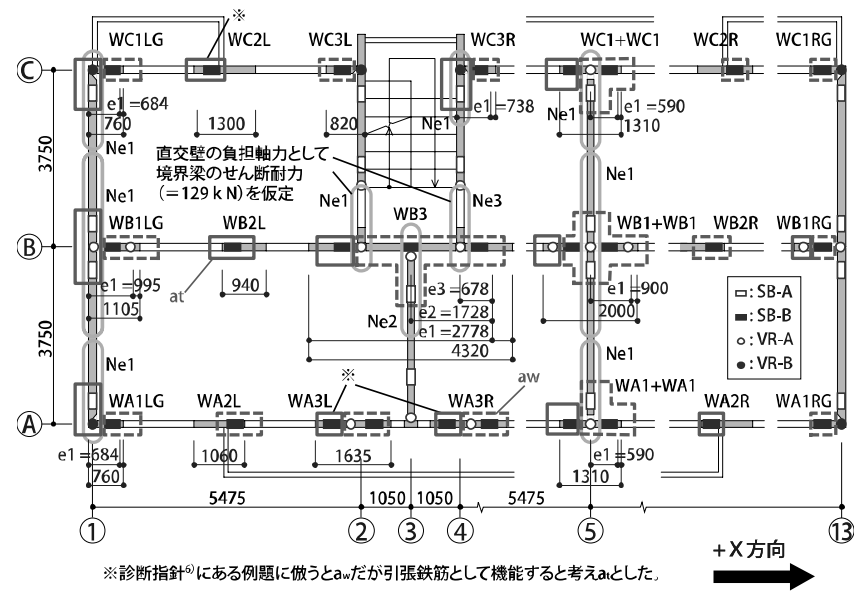

図 16 検討対象建物の住戸平面と耐震診断上の各設定
の算定範囲および直交壁の軸力 $\mathrm{N}_{\mathrm{e}}$ の算定範囲と直交壁の軸力によ る偏心モーメント算定用偏心距離 $\mathrm{e}$ を図 16 に示す。診断上の耐震壁 の符号は各階で共通である。診断指針では $\mathrm{a}_{\mathrm{t}}$ を引張り縁から $0.2 \ell$ または $200 \mathrm{~mm}$ 以内の範囲にあるものを算入するとしている。図 16 の $\mathrm{a}_{\mathrm{t}}$ の範囲は基本的にこれに準じているが, WA3L, WA3R およびWC2L 内の一部の鉄筋については, 引張側の鉄筋として十分機能している と考え, $a_{t}$ に算入した。直交壁の $\mathrm{N}_{\mathrm{e}}$ の算定範囲は隣接架構までの距 離の半分とし, 圧縮縁から直交壁までの距離から壁長りの $10 \%$ 差し 引いた数值を偏心距離 $\mathrm{e}(\mathrm{mm})$ とした。 $\mathrm{B}$ 構面 3 通りを中心とする耐 震壁 (WB3) では, 複数の直交壁が存在することから偏心距離と軸力 をそれぞれ $\mathrm{e}_{1}, \mathrm{e}_{2}, \mathrm{e}_{3}$ と $\mathrm{N}_{\mathrm{e} 1}, \mathrm{~N}_{\mathrm{e} 2}, \mathrm{~N}_{\mathrm{e} 3}$ のように表現した。診断指針 では, 直交壁の負担軸力 $\mathrm{N}_{\mathrm{e}}$ は, 耐力壁に直交する全ての壁で, 相隣 合う耐力壁がある場合は, 直交壁の負担軸力の $1 / 2$ としている。こ こで, WB3 の直交壁である 2 通りおよび 4 通りの階段室脇の壁は住 戸入口上部の梁（境界梁）によって接合されている。従って，2 通 りおよび 4 通りの直交壁からの WB3 の鉛直方向の拘束力は境界梁の せん断耐力が上限になり，(2)式で算出される同梁のせん断終局耐力 $129 \mathrm{kN}$ を拘束力とした。

診断指針では，連層耐震壁の当該階の曲げ降伏時のせん断力 $Q_{\mathrm{mu}}$ （N）は下式で定義されている。

$$
\begin{aligned}
Q_{m u} & =\frac{M_{u}}{y_{0} H}+Q_{m u b} \\
Q_{m u b} & =\left(k_{B}+k_{s}\right)\left(N_{o}+N_{e}\right) Z_{o}
\end{aligned}
$$

ここで， $M_{u}(\mathrm{Nmm})$ は連層耐震壁の当該階の脚部の終局曲げモー メント, $\mathrm{y}_{0}$ は反曲点高さ比, $\mathrm{H}(\mathrm{mm})$ は壁脚から建物頂部までの高さ である。 $\mathrm{y}_{0}$ は診断指針に準拠して $2 / 3$ とした。(4) 式第 2 項は壁に接 続する壁梁による曲げ破壊耐力上昇分で, 耐震壁軸力 $\mathrm{N}_{0}$ と直交壁軸 力 $\mathrm{N}_{\mathrm{e}}$ の和と, $\mathrm{k}_{\mathrm{B}}$ と $\mathrm{k}_{\mathrm{S}}$ の和および当該建物の設計時の地震力算出に 用いられる地域係数 $Z_{0}$ の積で定義されている。これは，壁梁の耐力 はある程度重量に比例して設計されるであろうことから, それに乗 じる係数を定義する形で規定されたものである。なお, $\mathrm{N}_{0}$ と $\mathrm{N}_{\mathrm{e}}$ の軸 力は, 壁重量と図 7 に示寸各壁の支配床重量および積載荷重の累加 により算出した。

$\mathrm{k}_{\mathrm{B}}$ と $\mathrm{k}_{\mathrm{S}}$ は (6) および $(7)$ 式で与えられ, それぞれ耐震壁の両側に接 続する壁梁の曲げ戻しおよび而震壁の曲げ引張側に接続する壁梁の せん断力による耐震壁の鉛直方向の拘束による壁の耐力向上に関す る係数である。

$$
\begin{aligned}
& k_{B}=\frac{2 n_{f}-1}{2 n_{f}} \alpha_{s} \alpha_{b} \alpha_{\ell} \alpha_{r} k_{0} \leq 0.6 \\
& k_{s}=\frac{\ell_{w}}{\ell_{s}} \frac{2 n_{f}-1}{2 n_{f}} \alpha_{s} \alpha_{b} \alpha_{\ell} \alpha_{r} k_{0} \leq 0.6
\end{aligned}
$$

上式で， $\left(2 \mathrm{n}_{\mathrm{f}}-1\right) / 2 \mathrm{n}_{\mathrm{f}}$ は階数による補正係数で， $\mathrm{n}_{\mathrm{f}}$ は当該階が支 持する床数である。 $\ell_{\mathrm{w}}(\mathrm{mm})$ は耐震壁の有効せいで $0.9 \ell$ とし， $\ell_{\mathrm{s}}$ は耐震壁の曲げ引張り側となる側の壁梁の内法長さで, $\mathrm{k}_{0}$ は設計時 に用いられた当該階の短期許容応力度設計用の震度 $(=0.2)$ である。 $\alpha_{\mathrm{s}}$ と $\alpha_{\mathrm{b}}$ は強度増加係数であり, それぞれ床板の寄与（スラブ筋の 梁への協力効果）によるもの（=1.5） と腰壁の効果によるものであ る。 $\alpha_{\mathrm{b}}$ は壁に接続する開口下の腰壁位置の壁梁の数に依存し, 1.0 
から 2.0 の值をとる。 $\alpha_{\ell}$ は水平荷重に対する応力に必要な強度を基 準として，鉛直荷重に対する設計により生じる余裕率（=1.1）であ り， $\alpha_{\mathrm{r}}$ は同じく配筋調整により生じる余裕率 (=1.3) である。(6), （7）式より，(4) 式第 2 項を診断指針に準拠した場合, 壁に接続する 梁の数と位置のみが考慮され, 梁の耐力は考慮されない。なお, $I_{s}$ 值算定時に用いる形状指標 $\mathrm{S}_{\mathrm{D}}$ と経年指標 T は共に 1.0 とした。

\section{2 壁梁による壁の曲げ耐力寄与を精査した場合の診断結果}

耐震診断は診断指針に準拠するが，壁梁の壁の曲げ耐力への寄与 については(4)式の第 2 項に (5) 式を用いるのではなく, 別途精査す る。この場合の本耐震診断を「壁梁精査診断」と呼び, 後述の耐震 診断の前提条件を変化させた場合の比較検討形に対する基本形とす る。(4)式による耐震壁の曲げ破壊時のせん断耐力は, 壁脚部および 壁梁の曲げ降伏が破壊機構として想定されており, 同式の第 1 項と 第 2 項がそれぞれによる耐力寄与分とされる。ここで, 第 2 項の $Q_{\text {mub }}$ 值について, (8)式より算出することを考える。これは, 図 17 に示 寸壁梁の曲げ戻しと耐震壁の曲げ引張側の鉛直上向きの変位を壁梁 が拘束する効果を壁の水平抵抗力の形で表現したものである。

$$
Q_{m u b}=\frac{\sum M_{u a}+\sum M_{u b}+\sum Q_{M u a} Q_{s u}}{\sum P_{i} H_{i}} \cdot \sum P_{i}
$$

ここで， $\mathrm{M}_{\mathrm{ua}}$ と $\mathrm{M}_{\mathrm{ub}}(\mathrm{Nmm})$ はそれぞれ耐震壁の曲げ引張側と圧縮側 に接続する壁梁（腰壁を含む）の終局曲げモーメントであり，Q Q Q $(\mathrm{Nmm})$ は耐震壁の曲げ引張側に接続する壁梁の曲げ終局モーメント 時のせん断力である。また， $\ell_{\mathrm{su}}(\mathrm{mm})$ は曲げ引張側の壁梁から耐震 壁の圧縮縁までの長さ, $\mathrm{P}_{\mathrm{i}}(\mathrm{N})$ は $\mathrm{A}_{\mathrm{i}}$ 分布による地震荷重, $\mathrm{H}_{\mathrm{i}}(\mathrm{mm})$ は壁脚から建物頂部までの高さである（図 17）。

このような条件で実施した壁梁精查診断では, $\mathrm{C}_{\mathrm{t} 1}$ 值は 2 階で最も 小さく 0.74 であり, 解析での保有水平耐力時の $\mathrm{C}_{Q 1}$ 值と比較すると, $1 \%$ 大きい (表 6)。図 13 に壁梁精査診断における各階 $\mathrm{F}=1.0$ 時（層 間变形角 $\mathrm{R}=0.4 \%)$ の $\mathrm{C}_{\mathrm{t} 1}$ 值の原点からの割線を示した。解析では 1 階の層せん断力係数 $\mathrm{C}_{\mathrm{Qi}}$ 值が最小であったが， $\mathrm{C}_{\mathrm{t} 1}$ 值は 2 階で最小と なった。原因については十分解明できていないが, 診断では考慮さ れていない鉛直接合部のせん断破壊の影響なども考えられる。例え ば，診断では B 通り中央の 3 つの壁板により構成される図 4 の WB3 壁を一体化した耐震壁として扱っているが，解析では B 通り構面 4 通り付近の JQ ばねがせん断ずれ破壊している。

$\mathrm{I}_{\mathrm{s}}$ 值は 1 階で最小となり 0.82 である。 $\mathrm{C}_{\mathrm{t} 1}$ 值とは異なり $\mathrm{I}_{\mathrm{s}}$ 值が 1 階で最小となった理由は, 1 階では 2 階よりも脆性的な破壊形式と なる壁が多く， I 值を算出する際に強度型の算定式となったためで ある。崩壊形は, 直交壁を持たない壁で水平接合部のずれ破壊およ び壁のせん断破壊が多いものの, 全体としては壁の曲げ降伏が支配 的であった。既往の実大実験で確認された水平接合部のずれ破壊が 破壞形式となる耐震壁も存在した。

壁梁の水平抵抗力への寄与を確認する目的で, (4) 式の第 2 項を 無視して診断した場合， $C_{\mathrm{t} 1}$ 值は 1 階で最も小さく 0.19 であり $74 \%$ 低下した。また, 解析で壁梁を含めない場合の保有水平耐力時の $\mathrm{C}_{Q 1}$ は 0.20 であり, 両者は概ね一致した。つまり, 水平耐力の $75 \%$ 程度 が壁梁の寄与分である（図 12）。

また, 診断では, 解析モデルと同様に建物の 1 通りから 5 通りま
での 1 階段室分を対象としたが, その場合, 図 1 の建物で 5 通りや 9 通りの位置にある桁行方向の壁耐力を過小評価することになる。 建物全体を対象に耐震診断を行った場合, 勒性指標 $\mathrm{C}_{\mathrm{t} 1}$ 值は 2 階で 最も低く 0.79 であり， $I_{s}$ 值は 1 階で最も低く 0.89 であった。 1 階 段室分の診断結果に比べ, $\mathrm{C}_{\mathrm{t} 1}$ 值が $7 \%$ 大きい結果となり, 建物全体 を対象に解析した場合も同程度の耐力上昇が予想できる。

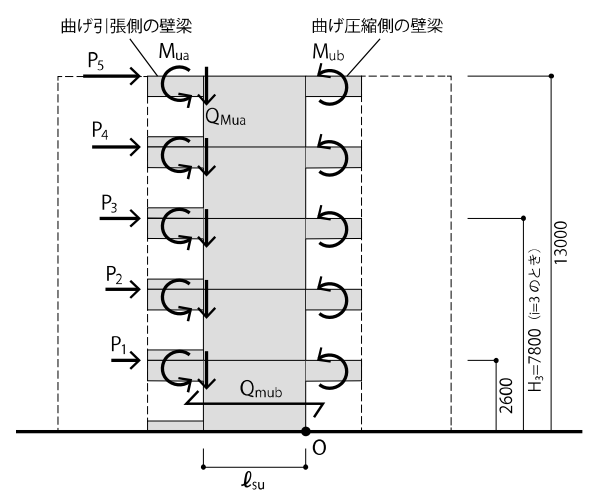

図 171 階の壁梁の耐震壁水平低力への寄与分

\section{3 解析と診断の前提条件が結果に及ぼす影響}

本節では, 耐震診断の基本形である壁梁精査診断に対して, 診断 条件を変更した 3 つ比較検討形について考察する。比較検討形の 内訳は，壁梁による耐力寄与を診断指針通りの略算とした場合の 2 通りと, 基本形と同様に壁梁の寄与を精査した場合の 1 通りである。 壁梁寄与を略算した 2 通りは，開口下部の成が小さい G4 梁（図 5) を無視した場合（以下「指針準拠診断」）と考慮した場合（以下「G4 考慮診断」）であり, 壁梁寄与精查の 1 通りは, 壁梁の耐力に床板の 寄与を考慮しない場合（以下「壁梁床無診断」）である。各診断ケー スの診断前提条件と $\mathrm{F}=1.0$ のときの強度指標 $\mathrm{C}_{\mathrm{t} 1}$ および構造耐震指 標 $I_{\mathrm{s}}$ 值を表 6 に整理した。

指針準拠診断での $\mathrm{C}_{\mathrm{t} 1}$ 值と $\mathrm{I}_{\mathrm{s}}$ 值はいずれも 2 階で最も小さく，共 に 0.75 であった (表 6)。これらは, 壁梁精查診断の值より $1 \%$ 高い。 また, $\mathrm{G} 4$ 考慮診断での $\mathrm{C}_{\mathrm{t} 1}$ 值と $\mathrm{I}_{\mathrm{s}}$ 值もいずれも 3 階で最も小さく, 共に 0.79 であった。これらは, 壁梁精查診断の值よりも $7 \%$ 高い。 一方, 解析での保有水平耐力時 $\mathrm{C}_{Q 1}$ は 0.73 であり, 壁の破壊形評価 に課題があるものの，建物全体としては，概ね妥当な評価が得られ た。一方，壁梁による耐力寄与を診断指針通りの略算とした場合， 扱う壁梁に注意をしなければ危険側の評価となる可能性がある。

壁梁精査診断と壁梁床無診断の $\mathrm{C}_{\mathrm{t} 1}$ 值は 2 階で最小であるのに対 し，診断準拠診断では 2 階と 3 階でほぼ同值，G4 考慮診断では 3 階で最小であることについて考察する。壁の曲げ耐力に対する壁梁 の寄与の割合に着目して, 壁梁精查診断と指針準拠診断を比較した 場合, 壁梁精査診断では 1-3 階の全ての壁の曲げ耐力に対する壁梁 の寄与の割合は，下階から 78\%，73\%，69\%であるのに対し，指針準 拠診断では $73 \% ， 69 \% ， 60 \%$ ある。指針準拠診断では 2 階と 3 階と 值にやや差があり, 壁の軸力に応じて算出される 3 階の壁梁耐力が 過小評価されていることになる。

また，指針準拠診断と G4 考慮診断では，強度型の評価式で算出 された 2 階および 3 階の $I_{s}$ 值が最小となった。壁梁精查診断では, 同階の $I_{s}$ 值は勒性型の評価式で算出され, 1 階の $I_{\mathrm{s}}$ 值よりも大きい。 この理由は, 壁に接続する梁の耐力評価が壁の破壊形式の評価に影 
響したと考えられる。つまり，診断指針に準拠した場合，壁の曲げ 耐力における梁の寄与は, 梁の耐力に関係なく, 壁に接続する梁の 数に応じて壁の負担軸力に比例して算出されるので, 負担軸力が比 較的大きい壁で寄与が大きくなる。これは, 長期荷重の負担率の大 きい壁ほど, 曲げ引張側に接続する壁梁の配筋量が多いことを仮定 しているが, 例えば図 16 の WB3 壁のように軸力が大きい壁に接続す る壁梁の耐力が他の壁梁の耐力よりも高い設計には必ずしもなって いない。つまり, 壁梁の壁の曲げ耐力への寄与は, 軸力が大きい壁 では過大評価となる可能性がある。水平力負担率の高い WB3 壁は壁 梁精查診断では曲げ破壊型であったのに対し，指針準拠診断と G4 考慮診断では, 梁の寄与が大きくなることにより, 曲げ耐力が増大 し，せん断破壊型となった。このことにより，同診断における 2,3 階の $I_{s}$ 值は強度型の評価式で決定されることになった。

基本形である壁梁精查診断では，(8)式より壁梁の水平抵抗力へ の寄与分を算出し，(4)式に壁梁による耐力上昇分として代入した。 診断指針通りに壁梁の水平抵抗力への寄与を計算した場合, 耐震壁 と直交壁の負担軸力の和が大きいWB3 の 1 階で 0.6 倍に低下した。 最も低下したのは WB1LGの 1 階で 0.3 倍に低下した。これは, B 構 面の壁梁の曲げ耐力が, 壁梁が接続する壁の負担軸力に寄らず, 全 階で同一なためである。また, 耐震壁と直交壁の負担軸力の和が小 さいWC1RGの 5 階では 17 倍に上昇した。このことは, WB3 壁の例の ように, 壁の破壊形式の評価に誤差を伴う可能性を示唆している。

開口上部の壁梁耐力に床板を考慮しない場合（壁梁床無診断）の $\mathrm{C}_{\mathrm{t} 1}$ 值と $\mathrm{I}_{\mathrm{s}}$ 值はそれぞれ 2 階と 1 階で最小となり，0.65 と 0.71 であ った。壁梁精查診断に比べて, それぞれ $12 \%$ と $13 \%$ 低下した。解析同 様に床板を壁梁耐力に考慮することによる水平耐力への影響が大き いことが確認できた。

\section{5. まとめ}

本研究では, 現存する標淮的な WPC 構造集合住宅建物を対象に, 桁行方向の耐震性能評価を目的とした静的増分解析モデルを作成し た。解析モデルでは，プレキャスト（PCa）耐震壁板の開口周囲の壁 梁および壁は線材に置換し, 弾性線材に曲げあるいはせん断の先行 破壊モードに応じた塑性変形ばねを設けて塑性変形を評価した。ま た，壁板の接合部を弾塑性ばねに置換した。これを用いた解析によ って得られた知見は以下のとおりである。

（1）地震荷重を $A_{i}$ 分布とした場合の桁行方向の保有水平耐力を算 出した。保有水平耐力時の 1 階の層せん断力係数 $\mathrm{C}_{Q 1}$ は 0.73 で あり，その時の変形角は $0.41 \%$ あった。崩壊形は 1 階脚部の 接合部の降伏および耐震壁間のずれを伴う壁梁と開口脇壁の 曲げ降伏であった。著者らによる同建物の張間方向の解析 ${ }^{1-3)}$ での保有水平耐力時 $\mathrm{C}_{Q 1}$ およびその時の変形角はそれぞれ 0.64 と $0.19 \%$ であり, 桁行方向の耐力の方が 1.14 倍大きく, 保有水 平耐力時変形角も大きかった。

（2）同建物の桁行方向について「既存壁式プレキャスト鉄筋コンク リート造建築物の耐震診断指針」 ${ }^{6)}$ （以下「診断指針」）に準じ た第 2 次耐震診断を実施した。壁梁による水平耐力向上分を精 查した場合 (壁梁精查診断), 勒性指標 $\mathrm{F}=1.0$ 時の強度指標 $\mathrm{C}_{\mathrm{t} 1}$ 值は 2 階で最も低く 0.74 となり, 解析での保有水平耐力時 $\mathrm{C}_{Q 1}$ とほぼ同值であった。 $I_{s}$ 值は 1 階で最も低く 0.82 であった。
耐震診断における崩壊形は直交壁のない壁の一部でせん断破 壊および水平接合部のずれ破壊となったが, 全体としては壁の 曲げ破壞で, 水平耐力が決定された。これは, 解析での梁降伏 型の崩壊形と概ね一致した。

（3）壁の曲げ耐力への接続壁梁の寄与は，診断と解析とで 70-80\% 程度と高い割合であることを確認した。建物全体としては両者 の接続壁梁の寄与度は概ね一致したが，個々の壁に着目すると， 診断による略算值は精算值の 0.3 倍から 17 倍とばらつきが大 きく，壁の崩壊形評価に影響することを示した。

（4）壁梁による水平耐力向上分を診断指針通りに算出した場合（指 針準拠診断)， $C_{\mathrm{t} 1}$ 值と $\mathrm{I}_{\mathrm{s}}$ 值はいずれも 2 階で最も小さく, 共に 0.75 であった。 $C_{\mathrm{t} 1}$ 值は壁梁精査診断の場合とほぼ同值となり, 解析の保有水平耐力時の $\mathrm{C}_{Q 1}$ に比べ $3 \%$ 高かった。指針準拠診断 は扱う壁梁に注意をしなければ危険側の評価となる可能性が あり, 壁の破壊形評価に課題があるものの, 建物全体としては, 概初妥当な評価が得られた。

（5）梁降伏が主体の崩壊形では, 梁耐力の評価が建物の挙動および 保有耐力に与える影響が大きいが, 本研究では, 開口上部の壁 梁の床板や上階開口下部の梁（腰壁）との一体化に関しては十 分評価できていない。梁の耐力評価の影響を確認寸る目的で床 板の梁耐力への寄与を考慮しない解析を行ったところ, 保有水 平耐力が $14 \%$ 低下した。また, 診断では, $\mathrm{C}_{\mathrm{t} 1}$ 值が 2 階で最も低 く0.65 となり，壁梁精査診断に比べ $12 \%$ 低下した。

\section{謝辞}

図版の作成に際して大関修平氏（首都大学東京大学院生）と臼井 亮氏 (同学部生)に協力いただいた。ここ記して謝意を表します。

\section{参考文献}

1）高木次郎，下錦田聡志，北山和宏，見波 進 : 既存壁式プレキャスト鉄 筋コンクリート構造集合住宅建物の静的解析モデルの構築, 而震壁に 新設開口を有する既存壁式プレキャスト鉄筋コンクリート構造集合住 宅建物の耐震性能評価 その 1 , 日本建築学会構造系論文集, 第 671 号, pp113-120, 2012.1

2）下錦田聡志，高木次郎，北山和宏，見波 進：既存壁式プレキャスト鉄 筋コンクリート構造集合住宅建物の解析モデルの改良と比較分析, 而 震壁に新設開口を有する既存壁式プレキャスト鉄筋コンクリート構造 集合住宅建物の耐震性能評価 その 2 , 日本建築学会構造系論文集, 第 680 号，pp1589-1598，2012. 10

3）高木次郎, 大関修平, 中橋芳貴 : 既存壁式プレキャスト鉄筋コンクリ 一ト構造集合住宅建物の鉛直接合部のせん断ばねモデル，日本建築学 会構造系論文集，第 693 号，pp2009-2017，2013.11

4）高木次郎, 北山和宏, 見波 進 : 新設開口補強を伴う既存壁式プレキャ スト鉄笳コンクリート構造耐震壁の数值解析モデル, 日本建築学会構 造系論文集，第 663 号, pp1015-1024，2011.5

5）和田芳宏，見波進，北山和宏，高木次郎：既存壁式プレキャス卜鉄筋 コンクリート構造而震壁における新設開口補強効果の実験的研究, コ ンクリート工学会年次報告集 Vol. 32, No. 2, pp1075-1080, 2010

6）日本建築防苂協会 : 既存壁式プレキャスト鉄筋コンクリート造建築物 の而震診断指針，第 2 版 3 刷， 2008

7）日本建築防災学会 : 既存鉄筋コンクリート造建築物の耐震診断基準同 解説, 2001 年改訂版 7 刷, 2001

8）日本建築学会 : 鉄筋コンクリート構造計算規準・同解説, 2010

9）日本建築学会：壁式プレキャスト鉄筋コンクリート造設計規準・同解 説, 1984

10）広澤雅也:公団型中層プレハブ, コンクリートジャーナル vol. 11, No. 11, pp42-56, 1973

11）建築構造学大系編集委員会 : 建築構造学大系 21 , 特殊コンクリート構 造, 第 1 版第 2 刷, 1973

12) Midas GEN Ver. 800, MIDAS Information Technology Co., LTD, 2013 